Article

\title{
Physiological and Qualitative Response of Cucurbita pepo L. to Salicylic Acid under Controlled Water Stress Conditions
}

\author{
Vahideh Biareh ${ }^{1}$, Farid Shekari ${ }^{2, *(D)}$, Saeed Sayfzadeh ${ }^{1}$, Hamidreza Zakerin ${ }^{1}$, Esmaeil Hadidi ${ }^{1}$, \\ José Gil Teixeira Beltrão ${ }^{3}$ and Andrea Mastinu $4, *$ D
}

1 Department of Agronomy and Plant Breeding, Faculty of Agriculture, Islamic Azad University, Takestan Branch, Takestan 49479, Iran; v_biare@yahoo.com (V.B.); saeedsayfzadeh@yahoo.com (S.S.); drzakerin5@gmail.com (H.Z.); es.hadidi@gmail.com (E.H.)

2 Department of Plant Production and Genetics, Faculty of Agriculture, University of Zanjan, Zanjan 45195, Iran

3 Faculty of Sciences and Technology, University of Algarve, 8005-139 Faro, Portugal; jbeltrao@ualg.pt

4 Department of Molecular and Translational Medicine, Division of Pharmacology, University of Brescia, 25123 Brescia, Italy

* Correspondence: shekari@znu.ac.ir (F.S.); andrea.mastinu@unibs.it (A.M.)

Citation: Biareh, V.; Shekari, F.;

Sayfzadeh, S.; Zakerin, H.; Hadidi, E.;

Beltrão, J.G.T.; Mastinu, A.

Physiological and Qualitative

Response of Cucurbita pepo L. to

Salicylic Acid under Controlled

Water Stress Conditions. Horticulturae

2022, 8, 79. https://doi.org/10.3390/

horticulturae 8010079

Academic Editor:

Alessandra Francini

Received: 13 November 2021

Accepted: 12 January 2022

Published: 14 January 2022

Publisher's Note: MDPI stays neutral with regard to jurisdictional claims in published maps and institutional affiliations.

Copyright: (C) 2022 by the authors. Licensee MDPI, Basel, Switzerland. This article is an open access article distributed under the terms and conditions of the Creative Commons Attribution (CC BY) license (https:// creativecommons.org/licenses/by/ $4.0 /)$.

\begin{abstract}
Limited water stress is one of the most important environmental stresses that affect the growth, quantity and quality of agronomic crops. This study was undertaken to investigate the effect of foliar applied salicylic acid (SA) on physiological responses, antioxidant enzymes and qualitative traits of Cucurbita pepo L. Plants exposed to water-stressed conditions in two years of field studies. Irrigation regimes at three soil matric potential levels $(-0.3,-1.2$ and $-1.8 \mathrm{MPa})$ and SA at four levels $(0.0,0.5,1.0$ and $1.5 \mathrm{mg} / \mathrm{L})$ were considered as main plot and sub-plots, respectively. The soil matric potential values (MPa) was measured just before irrigation. Results showed that under water stressed conditions alone, the amounts of malondialdehyde (MDA), hydrogen peroxide $\left(\mathrm{H}_{2} \mathrm{O}_{2}\right)$ and ion leakage were higher compared with control treatment. However, spraying of SA under both water stress and non-stress conditions reduced the values of the above parameters. Water stress increased CAT, APX and GR enzymes activity. However foliar application of SA led to the decrease of CAT, APX and GR under all soil matric potential levels. The amount of carbohydrates and fatty acids increased with the intensity of water stress and SA modulated this response. By increasing SA concentration both in optimum and stress conditions, saturated fatty acids content decreased. According to our data, the SA application is an effective approach to improve pumpkin growth under water stress conditions.
\end{abstract}

Keywords: antioxidant enzymes; citric acid; drought stress; fatty acid composition; foliar spraying; fruit sugar content; malondialdehyde

\section{Introduction}

Cucurbita pepo L. (C. pepo) is an annual herbaceous plant belonging to the Cucurbitaceae family. Seeds of this plant contain valuable active ingredients that play a major role in the treatment of the prostate gland and urinary tract inflammation and atherosclerosis. Consumption of these seeds increases the body's resistance to pathogens [1]. C. pepo seeds oil has no cholesterol, and is rich in $\omega 9$, and $\omega 6$ acids, fatty acids with more than $40 \%$ oleic acid, 33.1\% linoleic acid, and 14.7\% palmitic acid, and is effective in relieving joint pain, especially in chronic conditions and post-menopausal bone density [2,3]. The quantity, and quality of secondary metabolites such as alkaloids, glycosides, steroids and, essential oils in medicinal plants are affected by environmental factors including drought stress, nutrition, and plant growth regulators [4-14]. 
Drought is one of the most complex and destructive stresses in the world, which provokes a wide range of plant responses from cellular metabolism to change in growth rate and crop yield. Understanding biochemical and molecular drought reactions is essential for a comprehensive understanding of plant tolerance mechanisms to water scarcity [10,15-18]. Reactive oxygen species (ROS) production is one of the first biochemical reactions of the cell to biotic and abiotic stresses [19]. Under normal conditions, the production and elimination of ROS are thought to be in equilibrium, but environmental stresses disrupt and increase the production of ROS in plant cells [20]. Activated oxygen species are highly toxic to organisms and affect the structure and function of biological molecules. Their harmful effects on biological systems often result in damage to stomata and membranes, alterations of photosynthetic systems and metabolic reactions involving proteins, nucleic acids and lipids [20]. Drought stress leads the reduction in pumpkin plant height, leaf numbers, seed and fruit weight, seed number, width, and diameter [21,22]. In addition, it has a negative effect on physiological characteristics (e.g., antioxidant enzymes, pumpkin oil components, soluble protein content and photosynthetic pigments) [21-24].

Use of exogenous growth regulators has been shown to reduce the effects of abiotic and biotic stresses in plants. Salicylic acid (SA) and its related compounds have been effective in reducing the impacts of many environmental stresses [25,26]. SA is produced by root cells and plays a central role in regulating various physiological processes such as growth, plant evolution, ion uptake, photosynthesis, and germination [25]. In addition, SA can be changed, increased or reduced depending on $\mathrm{H}_{2} \mathrm{O}_{2}$ concentration [27], catalase (CAT), and peroxidase (POX) activities [28]. It is assumed that SA modulates these activities via either its direct interaction with these enzymes [29] or by controlling their synthesis [30]. According to previous studies, SA has relieved the negative effect of drought stress on plants through the activation of anti-oxidative defense machinery and resulted in MDA content reduction and helping in the maintenance of fatty acid breakdown plays a vital role in maintaining the redox state of membrane proteins [29,30].

Limited literature is available on the response of the antioxidant defense system and changes in the fatty acid profile of C. pepo in drought stress conditions. The aim of the present study was to determine the effect of SA on physiological, biochemical, and qualitative responses of $C$. pepo under water-stressed conditions.

\section{Materials and Methods}

\subsection{Cultivation, Crop Husbandry, and Experimental Design}

The experiment was conducted in three replications at the Agricultural Research Station of the University of Zanjan, Iran, located at latitude $36^{\circ} 41^{\prime} \mathrm{N}$, longitude $48^{\circ} 27^{\prime} \mathrm{E}$, and $1620 \mathrm{~m}$ above sea level. The C. pepo was planted on 31 May 2016 and 29 May 2017. The length and width of each plot were 6 and $4 \mathrm{~m}$, respectively. Distance between rows was $2 \mathrm{~m}$ and distance between plants on the same row was $0.5 \mathrm{~m}$ (one plant $/ \mathrm{m}^{2}$ ). In each plot, three planting lines were considered, so there were 36 plants in each plot. Pumpkin harvest time was on the third week of October in both years. Weather conditions (precipitation and temperature) of Zanjan University research station in years of 2016 and 2017 are presented in Table 1.

Table 1. Mean values of rain and temperature of Zanjan weather station in 2016 and 2017.

\begin{tabular}{|c|c|c|c|c|c|c|}
\hline \multirow[b]{2}{*}{ Months } & \multicolumn{2}{|c|}{ Mean of Precipitation (mm) } & \multicolumn{2}{|c|}{ Mean of Temperature $\left({ }^{\circ} \mathrm{C}\right)$} & \multicolumn{2}{|c|}{ Evaporation (mm) } \\
\hline & 2016 & 2017 & 2016 & 2017 & 2016 & 2017 \\
\hline April & 2.6 & 2 & 10.7 & 9.5 & 3.1 & 2.9 \\
\hline May & 0.2 & 0.9 & 16.65 & 16.5 & 4.2 & 3.8 \\
\hline June & 0.01 & 0.5 & 22.3 & 19.8 & 7.1 & 6.5 \\
\hline July & 0.03 & 0.05 & 26.55 & 24.6 & 11.1 & 10.2 \\
\hline August & 0 & 0 & 25.9 & 26.85 & 10.4 & 11.2 \\
\hline September & 0.09 & 0 & 21.45 & 22.55 & 8.9 & 9.7 \\
\hline
\end{tabular}


Prior to the experiment, the soil was randomly sampled from the study field from 20-30 cm depth and transferred to the laboratory for characterization determination which are presented in Table 2. The soil texture was determined by the hydrometer method [31]. Several soil chemical characteristics were measured: electrical conductivity in the soil extract $\left(1: 2.5 w / v\right.$; units $\left.\mathrm{dS} \mathrm{m}^{-1}\right)$ [31]; available $\mathrm{N}$ by Kjheldal method using a Buchi K-437/K-350 digestion/distillation unit [31]; available P (Shimadzu UV 1208 model spectrophotometer, Olsen method) [31]; $\mathrm{pH}$ (use $0.1 \mathrm{M} \mathrm{BaCl}_{2}$ ) [1], organic matter (OM) (WalkyBlack wet oxidation method); exchangeable cations ( $\mathrm{Ca}, \mathrm{K}$, and $\mathrm{Mg}$ ) were extracted using ammonium acetate at pH 7.0 [32] and were determined using an Eppendorf Elex 636 model flame photometer.

Table 2. Physicochemical properties of the farm soil.

\begin{tabular}{cc}
\hline Type of Analysis & Values \\
\hline Organic matter (\%) & 1.21 \\
Electrical conductivity (\%) & 0.83 \\
pH & 8.18 \\
Total lime (\%) & 6.0 \\
Clay (\%) & 31 \\
Silt (\%) & 27 \\
Sand (\%) & 42 \\
Texture & Clay Loam \\
Total nitrogen $(\%)$ & 0.07 \\
Phosphorus (mg/kg) & 14.2 \\
Potassium $(\mathrm{mg} / \mathrm{kg})$ & 266 \\
Calcium $(\mathrm{meq} / \mathrm{L})$ & 2.0 \\
Magnesium $(\mathrm{meq} / \mathrm{L})$ & 1.0 \\
\hline
\end{tabular}

Three irrigation regimes (according to soil matric potential $-0.3,-1.2$, and $-1.8 \mathrm{MPa}$ ) and 4 levels of SA $(0.0,0.5,1.0$, and $1.5 \mathrm{mg} / \mathrm{L})$ were considered as the main plot, and sub-plots. The lower value of matric potential considered as soil suction near to field capacity and the highest value as a value which may produce water stress in most plants. The irrigation intervals were determined by TDR (Time domain reflectometer) device measurements as described by Noborio and colleagues [33]. A sample of farm soil was transferred to the laboratory and after drying in an oven at $105^{\circ} \mathrm{C}, 2 \mathrm{~kg}$ of it was poured into a pot and saturated with water. Then the TDR device probes were installed in $30 \mathrm{~cm}$ depth of soil. After $24 \mathrm{~h}$, the weight of the pot was measured for 10 days, and the soil moisture was determined with the following equation.

$$
\theta v=\left[\left(M_{i}-M_{i-1}\right) \div M_{d r y}\right] \times \rho b \times 100
$$

In this equation, $\theta_{\mathrm{v}}$, volumetric soil moisture $(\%) ; \mathrm{M}_{\mathrm{i}}-\mathrm{M}_{\mathrm{i}-1}$, pot weight on days $\mathrm{i}$ and $i-1$, respectively; $M_{d r y}$, dry soil weight $(\mathrm{kg})$; and $\rho_{b}$, bulk density. Plants irrigated with taps according to their soil moisture regime.

Water stress was imposed two weeks after the spraying of SA and continued until fruit size reached to 5 to $7 \mathrm{~cm}$. SA was sprayed by manual sprayer at the five to six leaf stage.

Simultaneously with weight measurement, soil moisture was read by TDR. Finally, a relationship was established between the measured, and read values of the TDR device. Then, the probe of the device was installed in the field, and before irrigation, it was read and with the determined relationship, the amount of moisture was determined, and the amount of irrigation water was given to the plant. 


\subsection{Measured Traits}

The studied characteristics included MDA (Malondialdehyde), ion leakage, CAT (Catalase), APX (Ascorbate Peroxidase), POX (Peroxidase), GR (Glutathione Reductase) and SOD (Superoxide Dismutase), which were sampled and measured at flowering stage of C. pepo.

Leaf MDA concentration was determined by squashing $0.5 \mathrm{~g}$ of fresh leaf in a $20 \%$ solution of trichloro acetic acid TCA containing $0.5 \%$ thiobarbituric acid, and then was mixed for $25 \mathrm{~min}$. The temperature was set to $95{ }^{\circ} \mathrm{C}$ in the Bain-Marie bath. The mixture was then cooled in an ice bath and the concentration of MDA was measured at $532 \mathrm{~nm}$ according to the method of Jha [34].

The membrane stability index was evaluated by measuring the amount of electrolyte leakage of the leaves. For this purpose, 15 leaf discs were transferred to tubes with a volume of $10 \mathrm{~mL}$ of distilled water and were placed at room temperature and low light intensity for $24 \mathrm{~h}$. The electrical conductivity of the distilled water with the samples (EC1) was measured by an EC meter. The test tubes were then placed in a boiling water bath $\left(95^{\circ} \mathrm{C}\right)$ for $15 \mathrm{~min}$ and after EC2 cooling they were re-measured and finally the electrolyte leakage was calculated using the following equation [35].

$$
\mathrm{EL} \%=[\mathrm{EC} 1 \div \mathrm{EC} 2] \times 100
$$

where EL: Electrolytic leakage, EC1 and EC2 Electrolytic conductivity before and after boiling water bath, respectively.

\subsection{Antioxidant Enzymes Assay}

Peroxidase (POX) (EC. 1.11.17): as described by Chen [36], POX activity was assayed spectrophotometrically with some modifications using 4802 UV VIS spectrophotometer (Cole Parmer, Vernon Hills, IL, USA). Specific activity was expressed as mmol o-dianisidine oxidized $\mathrm{mg}$ protein ${ }^{-1} \mathrm{~min}^{-1}$.

Ascorbate peroxidase (APX) (EC.1.11.1.11): Its assay was done by using the method mentioned by Asada and Takahashi [37] with some minor modifications. Enzyme activity was expressed as mmol ascorbate oxidized $\mathrm{mg}_{\text {protein }}{ }^{-1} \mathrm{~min}^{-1}$.

Catalase (CAT) (EC.1.11.1.6): its activity was measured by estimating the breakdown of $\mathrm{H}_{2} \mathrm{O}_{2}$, which was determined at $240 \mathrm{~nm}$ as stated by Trawczyńska [38]. The enzyme activity was expressed as $\mathrm{mg}^{-1}$ protein $\mathrm{min}^{-1}$.

Glutathione Reductase (GR) (C 1.6.4.2): the activity of GR was determined by using the method presented by Lee and Lee [39] by measuring the oxidation of NADPH at 340 $\mathrm{nm}$. Enzyme activity was expressed as $\mu \mathrm{M}$ NADPH oxidized $\mathrm{mg}_{\text {protein }}{ }^{-1} \mathrm{~min}^{-1}$.

Superoxide dismutase (SOD) (EC 1.15.1.1): SOD was measured by the method as proposed by Zhang [40] in which the inhibition of the photochemical reduction of NBT was monitored. One unit of activity was defined as the amount of enzyme required to inhibit $50 \%$ of the NBT reduction rate in the controls containing no enzymes.

\subsection{Quality Parameters}

Five $g$ of mesocarp tissue was cut and sliced then homogenized with $25 \mathrm{~mL}$ of distilled water. The $\mathrm{pH}$ of mesocarp was measured by using a $\mathrm{pH}$ meter (Model AZ-86502, AZ Taiwan). The mixture was titrated with $0.1 \mathrm{M} \mathrm{NaOH}$ to $\mathrm{pH} 8.3$ and the results were expressed in \% citric acid, as abundant acid in C. pepo [41]. The total sugar content was determined by the anthrone method using visible light spectrophotometry [42]. Seeds oil content extracted with hexane. Seeds were washed with hexane, then the hexane was separated from oil by evaporation and distillation [43]. Fatty acid methyl esters were measured from extracted oil by the method of Weatherly [44] with gas chromatography (Shimadzu GC-14A, Kyoto, Japan). 


\subsection{Statistical Analysis}

Data were statistically analyzed using analysis of variance (ANOVA) by the Statistical Analysis System SAS computer software at $(p<0.01)$ (SAS, 2001). The means were analyzed by Duncan's multiple range test (DMRT) at $(p<0.05)$ by MSTATC. Prior to composite variance analysis, homogeneity of variance of experimental errors was tested using Bartlett's test.

\section{Results and Discussion}

These results of combined analyses of two years data indicated that irrigation regime at three soil matric potential levels, SA, and their interaction had a significant effect on all studied traits including MDA, ion leakage, antioxidant enzymes (CAT, APX, POX, GR, and SOD), and quality parameters. According to ANOVA results, there was no interaction between the year and the treatments, so the reported values are the average of two years (Table 3 ).

Table 3. Analysis of variance of the effect of drought stress and SA application.

\begin{tabular}{|c|c|c|c|c|c|c|c|c|c|c|c|}
\hline S.O.V & DF & MDA & EL & CAT & GR & POX & APX & SOD & $\begin{array}{c}\text { Mesocarp } \\
\text { pH }\end{array}$ & $\begin{array}{l}\text { Titratable } \\
\text { Acid }\end{array}$ & $\begin{array}{c}\text { Soluble } \\
\text { Carbohydrates }\end{array}$ \\
\hline Year $(\mathrm{Y})$ & 1 & 0.001 & 0.114 & 0.015 & 0.016 & 0.028 & 0.006 & 0.030 & 0.001 & 0.00001 & 0.335 \\
\hline Error (Year $\times$ Rep) & 4 & 0.65 & 22.512 & 0.0001 & $62.141 * *$ & $0.005^{* *}$ & $0.101^{* *}$ & 64.645 & 0.1282 & 0.0012 & 8.519 \\
\hline Water stress $(\mathrm{A})$ & 2 & $0.940 * *$ & $248.643^{* *}$ & $1.748^{* *}$ & 1368.103 ** & $1.099 * *$ & $6.196 * *$ & 1.094 & $1.3684^{* *}$ & $0.1387^{* *}$ & $924.304^{* *}$ \\
\hline $\mathrm{Y} \times \mathrm{A}$ & 2 & 0.0001 & 0.002 & 0.0001 & 0.0001 & 0.000 & 0.0001 & 0.0001 & 0.00002 & 0.00002 & 0.006 \\
\hline Error & 8 & 0.055 & 5.925 & 0.002 & 0.176 & 0.001 & 0.013 & 0.455 & 0.0505 & 0.0022 & 3.684 \\
\hline Salicylic Acid (B) & 3 & $0.038^{* *}$ & $1732.814^{* *}$ & $0.521 * *$ & $694.606^{* *}$ & $0.048 * *$ & $3.102 * *$ & $125.908^{* *}$ & $4.0306^{* *}$ & $0.1107^{* *}$ & $3354.688^{* *}$ \\
\hline $\mathrm{Y} \times \mathrm{SA}$ & 3 & 0.0001 & 0.00003 & 0.0001 & 0.0001 & 0.000 & 0.0001 & 0.0001 & 0.0000007 & 0.00000025 & 0.002 \\
\hline $\mathrm{A} \times \mathrm{B}$ & 6 & $0.021^{* *}$ & $76.563^{* *}$ & $0.043^{* *}$ & $11.243^{* *}$ & $0.081^{* *}$ & $0.092 * *$ & 2.351 * & $0.2859^{* *}$ & $0.0218^{* *}$ & $160.005^{* *}$ \\
\hline $\mathrm{Y} \times \mathrm{A} \times \mathrm{B}$ & 6 & 0.0001 & 0.001 & 0.0001 & 0.0001 & 0.0001 & 0.0011 & 0.0001 & 0.000005 & 0.0000006 & 0.002 \\
\hline Error & 36 & 0.005 & 3.68 & 0.001 & 1.113 & 0.0001 & 0.002 & 0.729 & 0.0402 & 0.0007 & 5.99 \\
\hline $\mathrm{CV}$ & - & 3.25 & 2.83 & 2.98 & 2.97 & 2.32 & 2.01 & 1.42 & 3.25 & 4.97 & 2.13 \\
\hline
\end{tabular}

The degree of lipid peroxidation, measured in terms of MDA content, is one of the determinants which indicate the severity of stress experienced by any plant [45,46]. According to the results, the lowest value of the MDA was observed in the non-stress conditions $(-0.3 \mathrm{MPa})$ and under all SA treatments. SA Foliar application resulted in significant decline in MDA content in leaves under both normal and stress conditions. By increasing soil matric suction, the observed values in MDA were significantly increased (Figure 1).

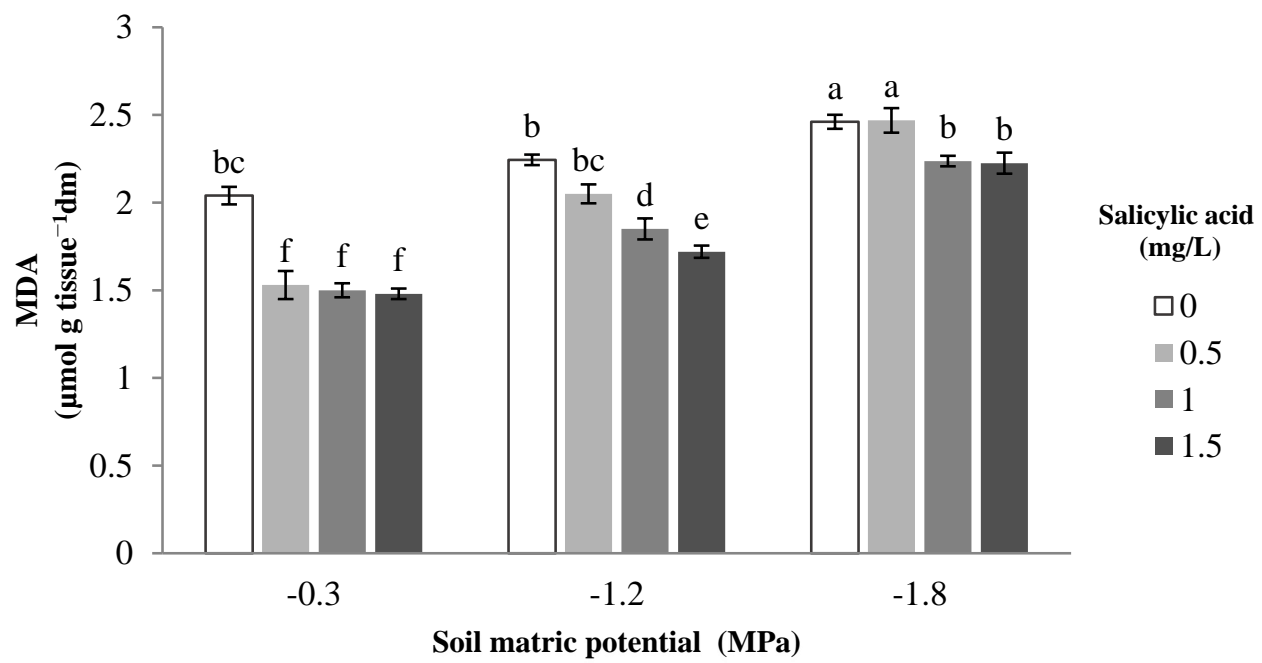

Figure 1. Mean comparisons for the interaction effects of controlled water stress and foliar application of SA on MDA concentration of Pumpkin. 
The highest MDA was found in severe water stress and non-sprayed and $0.5 \mathrm{mg} / \mathrm{L} \mathrm{SA}$ as mentioned by the findings of Agarwal and colleagues [47]. In particular, they reported that SA treatments of wheat leaves under water stress conditions resulted in reduced amount of MDA. Lipid peroxidation in the cell membranes is reported to be one of the most challenging and detrimental effects of water stress on the membranes of all the cells exposed to varied degree of stress [48]. Chen and colleagues mentioned that MDA content increased in soybean wild type plants in response to drought stress [49].

Results also indicated that while water stress resulted in an increase in ion leakage, SA led to the decrease in ion leakage under all water regimes (Figure 2).

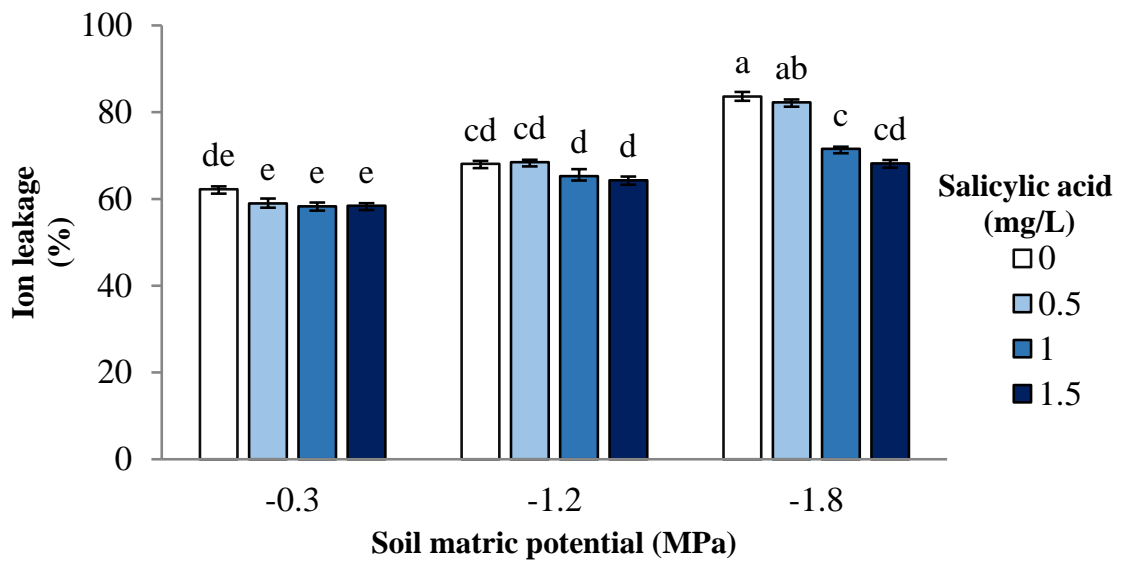

Figure 2. Interaction effects of controlled water stress and foliar application of SA on ion leakage percent of pumpkin.

Like to MDA, under non stress conditions there was not any significant differences between SA concentrations. On the other hand, mild and severe water stress led to show differences among SA concentration. This effect was showed especially in $-1.8 \mathrm{MPa}$ treatment. Since there is a direct relationship between ion leakage and cell permeability, the maintenance of cell membrane integrity should be considered as an important strategy for developing drought resistance. Abid and colleagues reported that among higher membrane stability and, lower MDA concentration which may produce by lipid peroxidation has strong correlation [50]. Accordingly, in comparison of evaluation of water shortage on two apple rootstocks, Malus prunifolia and Malus hupehensis as drought tolerant, and sensitive respectively, Wang stated water shortage altered ultra-structural of organelles in both species, but tolerant species showed more integrity in cell structure than sensitive [51].

According to results, water stress increased CAT, APX, and GR enzymes activity (Table 4). However foliar application of SA led to the decrease of CAT, APX, and GR under all irrigation regimes at three soil matric potential, except for APX activity under 0.5 and $1 \mathrm{mg} / \mathrm{L} \mathrm{SA}$ application in $-1.8 \mathrm{MPa}$ treatment. Based on the results, SA reduced APX under well-watered, and mild stress $C$. pepo; however, it was increased or had no significant effect under severe water stress. This reduction in APX was noticeable under non-stress treatment $(-0.3 \mathrm{MPa})$ (Table 4$)$. This result agreed with Santisree and colleagues who reported that SA is an inhibitor of APX [28]. In this case, APX reduces $\mathrm{H}_{2} \mathrm{O}_{2}$ cycle into the water by using ascorbate as particular electron donor. According to the present study, SA spraying increased SOD activation under all irrigation regimes at three soil matric potential levels (Table 4). In all matric potential levels, the highest value of SOD was found in $1.5 \mathrm{mg} / \mathrm{L}$ of SA. There was an upward trend in SA concentrations and SOD activity in water stress treatments. These results are consistent with results obtained from other various plants species [52-55]. Spraying of SA in different water regimes showed different reaction in C. pepo plants. Under non stress condition, by increasing SA concentrations POX activity showed an upward trend. But in mild, and severe water stress there was a slight increment or even reduction in POX activity (Table 4). In all water treatments, spraying of SA imposed a downward trend in GR activity (Table 4). 
Table 4. Interaction effects of controlled water stress and foliar application of SA on antioxidants activity of pumpkin. (The matric potential (MPa) value was measured just before irrigation).

\begin{tabular}{|c|c|c|c|c|c|c|}
\hline $\begin{array}{l}\text { Soil Matric } \\
\text { Potential } \\
\text { (M Pa) }\end{array}$ & $\begin{array}{l}\text { Salicylic Acid } \\
\text { (mg/L) }\end{array}$ & $\begin{array}{c}\text { Catalase } \\
\left(\mathrm{mg}^{-1} \text { Protein) }\right.\end{array}$ & $\begin{array}{c}\text { GR } \\
(\mathrm{mg} / \mathrm{min} \mathrm{FW})\end{array}$ & $\begin{array}{c}\text { POX } \\
\left(\mathrm{mg}^{-1} \text { Protein) }\right.\end{array}$ & $\begin{array}{c}\text { APX } \\
(\mathrm{mg} / \mathrm{min} \text { FW) }\end{array}$ & $\begin{array}{c}\text { SOD } \\
(\mathrm{mg} / \mathrm{min} \text { FW) }\end{array}$ \\
\hline \multirow{4}{*}{-0.3} & 0.0 & $1.061^{\mathrm{g}}$ & 35.89 ef & $0.263^{k}$ & $2.27^{\mathrm{e}}$ & $57.01^{\mathrm{e}}$ \\
\hline & 0.5 & $0.963^{h}$ & $28.78^{h}$ & $0.364^{j}$ & $1.96^{\mathrm{g}}$ & $58.91^{\mathrm{d}}$ \\
\hline & 1.0 & $0.814^{\mathrm{i}}$ & $23.91^{i}$ & $0.455^{\mathrm{g}}$ & $1.58^{\mathrm{h}}$ & $62.02 \mathrm{bc}$ \\
\hline & 1.5 & $0.775^{\mathrm{j}}$ & $21.42^{j}$ & $0.551^{\mathrm{e}}$ & $1.27^{\mathrm{i}}$ & $63.01^{\mathrm{ab}}$ \\
\hline \multirow{4}{*}{-1.2} & 0.0 & $1.386^{b}$ & $43.69^{b}$ & $0.427^{\mathrm{h}}$ & $2.88^{a}$ & $56.83^{e}$ \\
\hline & 0.5 & $1.205^{\mathrm{e}}$ & $36.54^{\mathrm{e}}$ & $0.395^{\mathrm{i}}$ & $2.58^{b c}$ & $58.66^{d}$ \\
\hline & 1.0 & $1.118^{\mathrm{f}}$ & $34.24^{\mathrm{f}}$ & $0.445^{\mathrm{g}}$ & $2.29^{e}$ & $60.85^{c}$ \\
\hline & 1.5 & $1.116^{\mathrm{f}}$ & $32.21 \mathrm{~g}$ & $0.491^{f}$ & $2.11^{\mathrm{f}}$ & $63.69^{\mathrm{a}}$ \\
\hline \multirow{4}{*}{-1.8} & 0.0 & $1.821^{a}$ & $52.99^{a}$ & $0.618^{d}$ & $2.46^{\mathrm{c}}$ & $58.00 \mathrm{de}$ \\
\hline & 0.5 & $1.389^{b}$ & $41.62^{\mathrm{c}}$ & $0.678^{c}$ & $2.7^{\mathrm{b}}$ & $58.91^{\mathrm{d}}$ \\
\hline & 1.0 & $1.301^{c}$ & $38.99 \mathrm{~d}$ & $0.737^{b}$ & $2.52^{b c}$ & $62.31^{\mathrm{a}-\mathrm{c}}$ \\
\hline & 1.5 & $1.256^{\mathrm{d}}$ & $36.29^{e}$ & $0.77^{\mathrm{a}}$ & $2.44^{\mathrm{e}}$ & $62.52^{\mathrm{ab}}$ \\
\hline
\end{tabular}

When there is not a balance between ROS production and the rate of antioxidant defense system activation, oxidative stress may occur [56]. Regarding the decrease in CAT, APX, and GR under all matric potential levels, water stress is inevitably associated with increased oxidative stress due to enhanced accumulation of ROS, particularly $\mathrm{O}_{2}{ }^{-}$ and $\mathrm{H}_{2} \mathrm{O}_{2}$ in chloroplasts, mitochondria, and peroxisomes. As a result, the induction of antioxidant enzyme activities is a general adaptation strategy which plants use to overcome oxidative stresses [48]. The potential of APX to metabolize $\mathrm{H}_{2} \mathrm{O}_{2}$ depends on the redox state of such compounds. APX and GR are believed to act along with $\mathrm{H}_{2} \mathrm{O}_{2}$ scavenging during environmental stresses [57]. It has been suggested that the coordinated activity of different $\mathrm{H}_{2} \mathrm{O}_{2}$-scavenging enzymes plays a part in the plant redox homeostasis [58]. Drought and/or osmotic stresses lead to significant increase of ROS in plant cells. SOD, CAT, and POX are the major affiliates that scavenge ROS both via enzymatic and nonenzymatic mechanisms. However, environmental stimuli such as light, temperature, water, and other factors are in charge of stimulating these mechanisms [8]. Roshdy and colleagues reported high value of CAT and POX activities of strawberry leaves by increasing salinity levels and SA concentration [59]. There are some reports about the effects of SA on transit accumulation of ABA and control of antioxidant enzymes activity on the response of the plants to drought stress [60].

Results of this study showed that under optimal water condition, mesocarp $\mathrm{pH}$ was lower than water stress treatments. Spraying of SA also increased the $\mathrm{pH}$ under all matric potential levels (Figure 3). One reason for increasing of mesocarp $\mathrm{pH}$ under water stress condition may be due to significant decrease of citric acid content (Figure 4) and accumulation of carbohydrates (Figure 5). Furthermore, the multiple alterations induced by water stress can mobilize abscisic acid which seems to be involved in the alkalinization of plant systems [61]. 


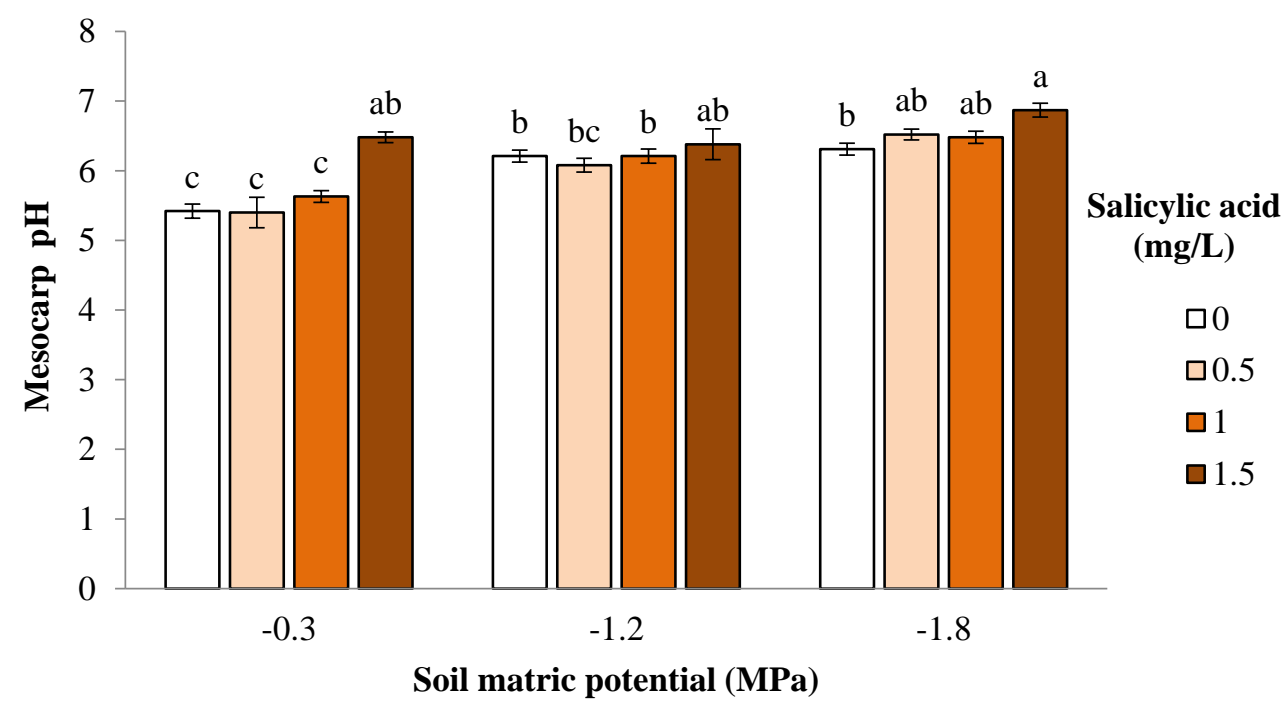

Figure 3. Interaction effects of controlled water stress and foliar application of SA on mesocarp $\mathrm{pH}$ of Pumpkin.

In contrast to $\mathrm{pH}$, titratable acid decreased by increasing stress intensity and SA concentrations (Figure 4). Across all matric potential levels, increasing SA concentration decreased citric acid content in mesocarp tissue. The highest value for titratable citric acid was found in $-0.3 \mathrm{MPa}$ and in $0,0.5$, and $1 \mathrm{mM} \mathrm{SA}$ spraying. The lowest amount of this trait was in the $-1.8 \mathrm{MPa}$ and $1.5 \mathrm{mM} \mathrm{SA}$ which had significant differences with other treatments. The changes in $\mathrm{pH}$ of mesocarp tissue may affect the quality of $C$. pepo flesh sensory [62]. Roshdy showed a significant effect of salinity levels and SA foliar application on the fruits' quality traits of strawberry fruits cv. Camarosa, including total soluble solids, ascorbic acid, and titratable acidity [59].

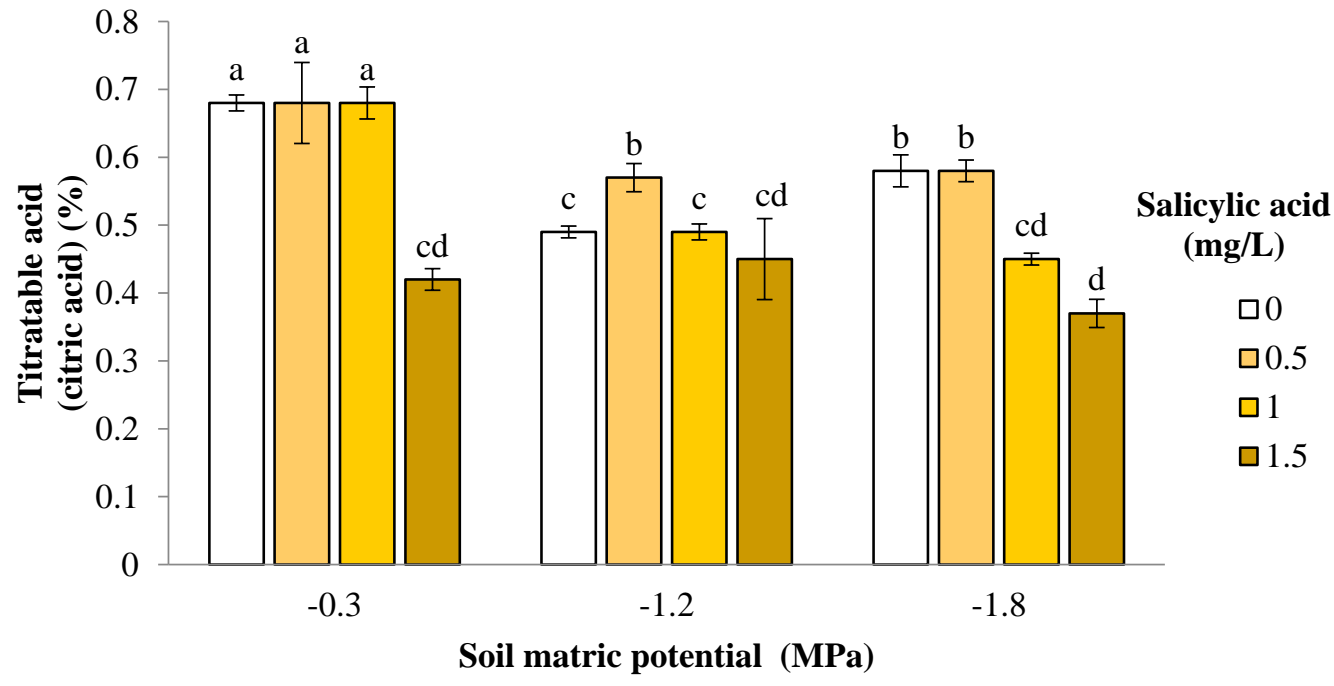

Figure 4. Interaction effects of controlled water stress and foliar application of SA on titratable acid of Pumpkin.

Soluble carbohydrates were lower in favorite water conditions than water stress treatments (Figure 5). In general, the amount of soluble carbohydrates presented increasing trend from zero to highest concentration of SA. The lowest value of soluble carbohydrates was found in control and $0.5 \mathrm{mM} \mathrm{SA}$ at $-0.3 \mathrm{MPa}$ and highest value in $-1.8 \mathrm{MPa}$ and $1.5 \mathrm{mM}$ SA. The accumulation of sugars in fruit tissue under stress conditions may be due to the catabolic process leads to degradation of starch into soluble sugars which enters the metabolic pool as osmoregulation and osmotic adjustment. It is reported that under the 
water stress condition, respiration intensity was higher than in the control [63]. Other results showed that in tomato fruits a decrease in soil available water lead to a decrease in fruit size and number and water content, but increased blossom end rot, sugar concentration as glucose and fructose, color intensity, and $\mathrm{CO}_{2}$ and ethylene production in fruit tissue [64]. They revealed that respiration intensity in fruits from deficit irrigation treatments was higher than control. There are some reports about the effects of SA on SC accumulation in fruits both in control and stress conditions. Ghaderi and colleagues stated that SA spraying in strawberry (Fragaria sp.) plants increased SC content in fruits especially under water stress conditions [65]. Similarly, Demiralay reported increasing SC and proline content in Ctenanthe leaves PEG treatment [66]. Higher accumulation of SC in tomato promoted by SA foliar application has been reported [67].

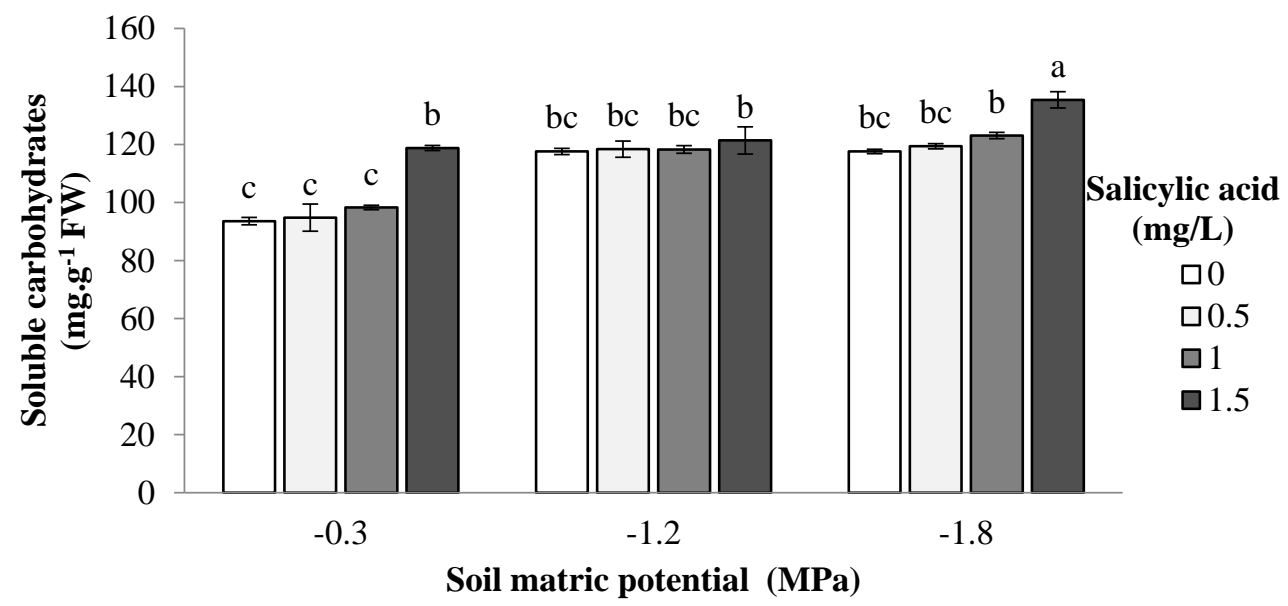

Figure 5. Interaction effects of controlled water stress and foliar application of SA on soluble carbohydrates of pumpkin.

Fatty acid composition of extracted oil from seeds was affected by both SA and water stress. Under optimum water conditions the content of stearic (18:0) and palmitic (16:0) acid was lower than -1.2 and $-1.8 \mathrm{MPa}$ matric potential levels (Table 5). By increasing SA concentration both in optimum and stress conditions, saturated fatty acids content decreased. Oleic acid (18:1) content in extracted oil was increased by increasing stress intensity and SA concentration. The lowest value for this fatty acid was found in control treatment and the highest under -1.8 MPa and 1.5 mM SA. However, linoleic acid (18:2) decreased by increasing stress intensity but increased by increasing SA concentration. The highest amount for this fatty acid was observed under optimum irrigation regime and $1.5 \mathrm{mM} \mathrm{SA}$, and lowest was observed in $-1.8 \mathrm{MPa}$ and $0 \mathrm{mg} / \mathrm{L} \mathrm{SA}$.

Studies have shown the negative impact of heat and water stress on seed oil content in plants $[68,69]$. The disadvantageous effects of drought stress on the fatty acid composition were not clearly explained [70]. For instance, in soybean, Gao reported that palmitic, linoleic and linolenic acids decreased under water stress condition, while stearic and oleic acids were increased [71]. Similarly, Carrera and colleagues showed that water stress increased total oil and oleic acid concentrations and decreased linoleic and linolenic acid concentrations [72]. On the other hand, Ashrafi and Razmjoo found that in sunflower cultivars, oleic and stearic acid concentration decreased, palmitic acid was unaffected and linoleic acid increased under drought stress conditions [73]. The variations of the results among the studies were due to the timing and intensity of the drought stress during the different crop growth stages [72,74]. SA, through the expression of genes can affect the biosynthesis of secondary metabolites pathway, essential oil content and composition in plants $[75,76]$. 
Table 5. Interaction of irrigation regime at three soil matric potential levels and salicylic acid on some fatty acid composition (The soil matric potential (MPa) value was measured just before irrigation).

\begin{tabular}{|c|c|c|c|c|c|}
\hline $\begin{array}{c}\text { Soil Matric } \\
\text { Potential (MPa) }\end{array}$ & $\begin{array}{l}\text { Salicylic Acid } \\
(\mathrm{mg} / \mathrm{L})\end{array}$ & $\begin{array}{c}\text { 16:0 } \\
\text { Palmitic Acid }\end{array}$ & $\begin{array}{c}18: 0 \\
\text { Stearic Acid }\end{array}$ & $\begin{array}{c}\text { 18:1 } \\
\text { Oleic Acid }\end{array}$ & $\begin{array}{c}18: 2 \\
\text { Linoleic Acid }\end{array}$ \\
\hline \multirow{4}{*}{-0.3} & 0.0 & 9.6 & 5.3 & 26.4 & 38.1 \\
\hline & 0.5 & 9.5 & 5.8 & 26.5 & 38.2 \\
\hline & 1.0 & 8.6 & 4.7 & 28.4 & 40.5 \\
\hline & 1.5 & 7.7 & 4.3 & 28.3 & 44.8 \\
\hline \multirow{4}{*}{-1.2} & 0.0 & 12.8 & 6.9 & 31.3 & 31.4 \\
\hline & 0.5 & 12.4 & 6.8 & 32.1 & 31.0 \\
\hline & 1.0 & 11.6 & 6.4 & 32.4 & 32.5 \\
\hline & 1.5 & 11.2 & 6.5 & 34.1 & 33.6 \\
\hline \multirow{4}{*}{-1.8} & 0.0 & 14.6 & 7.3 & 33.8 & 28.0 \\
\hline & 0.5 & 15.2 & 5.4 & 34.4 & 28.1 \\
\hline & 1.0 & 13.5 & 5.8 & 35.4 & 31.8 \\
\hline & 1.5 & 13.6 & 6.3 & 35.5 & 32.7 \\
\hline
\end{tabular}

\section{Conclusions}

Controlled water stress induced some physiological changes in C. pepo plant. By decreasing the soil available water, damage in cell membrane and ion leakage increased dramatically. The highest MDA and ion leakage percentage were found in severe water stress and non-sprayed SA. Our results showed that the antioxidative enzymes, especially SOD and POX, play a vital role in the C. pepo to tolerate drought condition. SA application increased SOD and POX activation under all irrigation regimes. Moreover, foliar application of SA effectively mitigated $\mathrm{H}_{2} \mathrm{O}_{2}$ toxicity in cells and may overcome to some cases of stress damage. Both stress and SA spraying increased fruit quality in terms of increasing soluble carbohydrates and decreasing citric acid content. Regarding the oil quality, water stress increased saturated fatty acid content but spraying SA increased linoleic and oleic acid content.

Further studies are needed to understand the molecular mechanisms underlying the water stress response in C. pepo in the presence of salicylic acid.

Author Contributions: Conceptualization, V.B. and F.S.; methodology, V.B., F.S., S.S. and H.Z.; formal analysis, S.S., H.Z., E.H. and J.G.T.B.; investigation, V.B., F.S., S.S. and H.Z.; resources, A.M.; data curation, S.S., H.Z., E.H. and J.G.T.B.; writing—original draft preparation, F.S.; writing-review and editing, A.M.; funding acquisition, A.M. All authors have read and agreed to the published version of the manuscript.

Funding: This research received no external funding.

Data Availability Statement: The data will be made available on reasonable request.

Acknowledgments: Authors want to express great appreciation to Department of Plant Production and Genetics, Faculty of Agriculture, University of Zanjan, and University of Brescia for supporting necessary facilities for this work.

Conflicts of Interest: The authors declare no conflict of interest.

\section{Abbreviations}

MDA Malondialdehyde

EL Electrolytic leakage

CAT Catalase

GR Glutathione Reductase

POX Peroxidase

APX Ascorbate peroxidase

SOD Superoxide Dismutase 


\section{References}

1. Murkovic, M.; Piironen, V.; Lampi, A.M.; Kraushofer, T.; Sontag, G. Changes in chemical composition of pumpkin seeds during the roasting process for production of pumpkin seed oil (Part 1: Non-volatile compounds). Food Chem. 2004, 84, 359-365. [CrossRef]

2. Medjakovic, S.; Hobiger, S.; Ardjomand-Woelkart, K.; Bucar, F.; Jungbauer, A. Pumpkin seed extract: Cell growth inhibition of hyperplastic and cancer cells, independent of steroid hormone receptors. Fitoterapia 2016, 110, 150-156. [CrossRef]

3. Richter, D.; Abarzua, S.; Chrobak, M.; Vrekoussis, T.; Weissenbacher, T.; Kühn, C.; Schulze, S.; Kupka, M.S.; Friese, K.; Briese, V.; et al. Effects of Phytoestrogen Extracts Isolated from Pumpkin Seeds on Estradiol Production and ER/PR Expression in Breast Cancer and Trophoblast Tumor Cells. Nutr. Cancer 2013, 65, 739-745. [CrossRef] [PubMed]

4. Abate, G.; Zhang, L.; Pucci, M.; Morbini, G.; Mac Sweeney, E.; Maccarinelli, G.; Ribaudo, G.; Gianoncelli, A.; Uberti, D.; Memo, M.; et al. Phytochemical Analysis and Anti-Inflammatory Activity of Different Ethanolic Phyto-Extracts of Artemisia annua L. Biomolecules 2021, 11, 975. [CrossRef]

5. Gupta, A.K.; Dhua, S.; Sahu, P.P.; Abate, G.; Mishra, P.; Mastinu, A. Variation in Phytochemical, Antioxidant and Volatile Composition of Pomelo Fruit (Citrus grandis (L.) Osbeck) during Seasonal Growth and Development. Plants 2021, $10,1941$. [CrossRef]

6. Gupta, A.K.; Rather, M.A.; Jha, A.K.; Shashank, A.; Singhal, S.; Sharma, M.; Pathak, U.; Sharma, D.; Mastinu, A. Artocarpus lakoocha Roxb. and Artocarpus heterophyllus Lam. Flowers: New Sources of Bioactive Compounds. Plants 2020, 9, 1329. [CrossRef] [PubMed]

7. Karimmojeni, H.; Rahimian, H.; Alizadeh, H.; Yousefi, A.R.; Gonzalez-Andujar, J.L.; Mac Sweeney, E.; Mastinu, A. Competitive Ability Effects of Datura stramonium L. and Xanthium strumarium L. on the Development of Maize (Zea mays) Seeds. Plants 2021, 10, 1922. [CrossRef] [PubMed]

8. Kumar, A.; Memo, M.; Mastinu, A. Plant behaviour: An evolutionary response to the environment? Plant Biol. 2020, 22, 961-970 [CrossRef]

9. Kumar, A.; Premoli, M.; Aria, F.; Bonini, S.A.; Maccarinelli, G.; Gianoncelli, A.; Memo, M.; Mastinu, A. Cannabimimetic plants: Are they new cannabinoidergic modulators? Planta 2019, 249, 1681-1694. [CrossRef]

10. Mahdavi, A.; Moradi, P.; Mastinu, A. Variation in Terpene Profiles of Thymus vulgaris in Water Deficit Stress Response. Molecules 2020, 25, 1091. [CrossRef]

11. Mastinu, A.; Ascrizzi, R.; Ribaudo, G.; Bonini, S.A.; Premoli, M.; Aria, F.; Maccarinelli, G.; Gianoncelli, A.; Flamini, G.; Pistelli, L.; et al. Prosocial Effects of Nonpsychotropic Cannabis sativa in Mice. Cannabis Cannabinoid Res. 2021. [CrossRef]

12. Mastinu, A.; Bonini, S.A.; Premoli, M.; Maccarinelli, G.; Mac Sweeney, E.; Zhang, L.; Lucini, L.; Memo, M. Protective Effects of Gynostemma pentaphyllum (var. Ginpent) against Lipopolysaccharide-Induced Inflammation and Motor Alteration in Mice. Molecules 2021, 26, 570. [CrossRef]

13. Ali, M.B.; Khatun, S.; Hahn, E.-J.; Paek, K.-Y. Enhancement of phenylpropanoid enzymes and lignin in Phalaenopsis orchid and their influence on plant acclimatisation at different levels of photosynthetic photon flux. Plant Growth Regul. 2006, 49, 137-146. [CrossRef]

14. Pirbalouti, A.G.; Samani, M.R.; Hashemi, M.; Zeinali, H. Salicylic acid affects growth, essential oil and chemical compositions of thyme (Thymus daenensis Celak.) under reduced irrigation. Plant Growth Regul. 2013, 72, 289-301. [CrossRef]

15. Noman, A.; Ali, Q.; Naseem, J.; Javed, M.T.; Kanwal, H.; Islam, W.; Aqeel, M.; Khalid, N.; Zafar, S.; Tayyeb, M.; et al. Sugar beet extract acts as a natural bio-stimulant for physio-biochemical attributes in water stressed wheat (Triticum aestivum L.). Acta Physiol. Plant. 2018, 40, 110. [CrossRef]

16. Naservafaei, S.; Sohrabi, Y.; Moradi, P.; Mac Sweeney, E.; Mastinu, A. Biological Response of Lallemantia iberica to Brassinolide Treatment under Different Watering Conditions. Plants 2021, 10, 496. [CrossRef] [PubMed]

17. Reza Yousefi, A.; Rashidi, S.; Moradi, P.; Mastinu, A. Germination and Seedling Growth Responses of Zygophyllum fabago, Salsola kali L. and Atriplex canescens to PEG-Induced Drought Stress. Environments 2020, 7, 107. [CrossRef]

18. Noryan, M.; Hervan, I.M.; Sabouri, H.; Kojouri, F.D.; Mastinu, A. Drought Resistance Loci in Recombinant Lines of Iranian Oryza sativa L. in Germination Stage. BioTech 2021, 10, 26. [CrossRef]

19. BBhusal, N.; Lee, M.; Han, A.R.; Han, A.; Kim, H.S. Responses to drought stress in Prunus sargentii and Larix kaempferi seedlings using morphological and physiological parameters. For. Ecol. Manag. 2020, 465, 118099. [CrossRef]

20. Gill, S.S.; Tuteja, N. Reactive oxygen species and antioxidant machinery in abiotic stress tolerance in crop plants. Plant Physiol. Biochem. 2010, 48, 909-930. [CrossRef]

21. Shahidan, N.; Othman, R.; Jaswir, I.; Hasyun-Hashim, Y. Effect of abiotic stress under light and dark conditions on carotenoid content in pumpkin (Cucurbita moshata) calluses. J. Fundam. Appl. Sci. 2018, 9, 861. [CrossRef]

22. Langeroodi, A.R.S.; Campiglia, E.; Mancinelli, R.; Radicetti, E. Can biochar improve pumpkin productivity and its physiological characteristics under reduced irrigation regimes? Sci. Hortic. 2018, 247, 195-204. [CrossRef]

23. Sinu, P.A.; Pooja, A.; Aneha, K. Overhead sprinkler irrigation affects pollinators and pollination in pumpkin (Cucurbita maxima). Sci. Hortic. 2019, 258, 108803. [CrossRef]

24. Seymen, M.; Yavuz, D.; Dursun, A.; Kurtar, E.S.; Türkmen, Ö. Identification of drought-tolerant pumpkin (Cucurbita pepo L.) genotypes associated with certain fruit characteristics, seed yield, and quality. Agric. Water Manag. 2019, 221, 150-159. [CrossRef]

25. Szalai, G. Influence of salicylic acid on phytochelatin synthesis in maize during Cd stress. Turk. J. Bot. 2013. [CrossRef] 
26. Pál, M.; Kovács, V.; Vida, G.; Szalai, G.; Janda, T. Changes induced by powdery mildew in the salicylic acid and polyamine contents and the antioxidant enzyme activities of wheat lines. Eur. J. Plant Pathol. 2012, 135, 35-47. [CrossRef]

27. Tanveer, M.; Shahzad, B.; Sharma, A.; Khan, E.A. 24-Epibrassinolide application in plants: An implication for improving drought stress tolerance in plants. Plant Physiol. Biochem. 2018, 135, 295-303. [CrossRef]

28. Santisree, P.; Jalli, L.C.L.; Bhatnagar-Mathur, P.; Sharma, K.K. Emerging Roles of Salicylic Acid and Jasmonates in Plant Abiotic Stress Responses. In Protective Chemical Agents in the Amelioration of Plant Abiotic Stress: Biochemical and Molecular Perspectives; John Wiley \& Sons Ltd.: Hoboken, NJ, USA, 2020; pp. 342-373. [CrossRef]

29. Xu, L.; Zhao, H.; Ruan, W.; Deng, M.; Wang, F.; Peng, J.; Luo, J.; Chen, Z.; Yi, K. Abnormal inflorescence meristem1 functions in Salicylic Acid Biosynthesis to Maintain Proper Reactive Oxygen Species Levels for Root Meristem Activity in Rice. Plant Cell 2017, 29, 560-574. [CrossRef]

30. Abbaspour, J.; Ehsanpour, A. The impact of salicylic acid on some physiological responses of Artemisia aucheri Boiss. under in vitro drought stress. Acta Agric. Slov. 2016, 107, 287-298. [CrossRef]

31. Tan, K.H. Soil Sampling, Preparation, and Analysis, 2nd ed.; Taylor \& Francis: Boca Raton, FL, USA, $2005 ;$ p. 623.

32. Pratt, P.F. Salinity, Sodium, and Potassium in an Irrigated Soil Treated with Bovine Manure. Soil Sci. Soc. Am. J. 1984, 48, 823-828. [CrossRef]

33. Noborio, K.; Horton, R.; Tan, C.S. Time Domain Reflectometry Probe for Simultaneous Measurement of Soil Matric Potential and Water Content. Soil Sci. Soc. Am. J. 1999, 63, 1500-1505. [CrossRef]

34. Jha, Y. Effects of Salinity on Growth Physiology, Accumulation of Osmo-Protectant and Autophagy-Dependent Cell Death of Two Maize Variety. Russ. Agric. Sci. 2018, 44, 124-130. [CrossRef]

35. Sairam, R.K.; Srivastava, G.C. Water Stress Tolerance of Wheat (Triticum aestivum L.): Variations in Hydrogen Peroxide Accumulation and Antioxidant Activity in Tolerant and Susceptible Genotypes. J. Agron. Crop Sci. 2001, 186, 63-70. [CrossRef]

36. Chen, J.; Song, L.; Dai, J.; Gan, N.; Liu, Z. Effects of microcystins on the growth and the activity of superoxide dismutase and peroxidase of rape (Brassica napus L.) and rice (Oryza sativa L.). Toxicon 2004, 43, 393-400. [CrossRef]

37. Asada, K. Production and Scavenging of Reactive Oxygen Species in Chloroplasts and Their Functions. Plant Physiol. 2006, 141, 391-396. [CrossRef]

38. Trawczyńska, I. New Method of Determining Kinetic Parameters for Decomposition of Hydrogen Peroxide by Catalase. Catalysts 2020, 10, 323. [CrossRef]

39. Lee, D.H.; Lee, C.B. Chilling stress-induced changes of antioxidant enzymes in the leaves of cucumber: In gel enzyme activity assays. Plant Sci. 2000, 159, 75-85. [CrossRef]

40. Zhang, J.; Li, H.; Xu, B.; Li, J.; Huang, B. Exogenous Melatonin Suppresses Dark-Induced Leaf Senescence by Activating the Superoxide Dismutase-Catalase Antioxidant Pathway and Down-Regulating Chlorophyll Degradation in Excised Leaves of Perennial Ryegrass (Lolium perenne L.). Front. Plant Sci. 2016, 7, 1500. [CrossRef] [PubMed]

41. Nielsen, S.S. Food Analysis, 4th ed.; Springer: New York, NY, USA; Dordrecht, The Netherlands, $2010 ;$ pp. xiv, 602.

42. Taufik, I.I.; Guntarti, A. Comparison of reduction sugar analysis method in cilembu sweet potato (Ipomoea batatas L.) using luff schoorl and anthrone method. J. Kedokt. Dan Kesehat. Indones. 2009, 7, 219-226. [CrossRef]

43. Karaosmanoğlu, H.; Üstün, N.Ş. Variations in fatty acid composition and oxidative stability of hazelnut (Corylus avellana L.) varieties stored by traditional method. Grasas Aceites 2019, 70, 288. [CrossRef]

44. Weatherly, C.A.; Zhang, Y.; Smuts, J.P.; Fan, H.; Xu, C.; Schug, K.A.; Lang, J.C.; Armstrong, D.W. Analysis of Long-Chain Unsaturated Fatty Acids by Ionic Liquid Gas Chromatography. J. Agric. Food Chem. 2016, 64, 1422-1432. [CrossRef]

45. Zhang, Y.; Luan, Q.; Jiang, J.; Li, Y. Prediction and Utilization of Malondialdehyde in Exotic Pine Under Drought Stress Using Near-Infrared Spectroscopy. Front. Plant Sci. 2021, 12, 735275. [CrossRef]

46. Khaleghi, A.; Naderi, R.; Brunetti, C.; Maserti, B.; Salami, S.A.; Babalar, M. Morphological, physiochemical and antioxidant responses of Maclura pomifera to drought stress. Sci. Rep. 2019, 9, 19250. [CrossRef] [PubMed]

47. Agarwal, S.; Sairam, R.K.; Srivastava, G.C.; Meena, R.C. Changes in antioxidant enzymes activity and oxidative stress by abscisic acid and salicylic acid in wheat genotypes. Biol. Plant. 2005, 49, 541-550. [CrossRef]

48. Ayala, A.; Muñoz, M.F.; Argüelles, S. Lipid Peroxidation: Production, Metabolism, and Signaling Mechanisms of Malondialdehyde and 4-Hydroxy-2-Nonenal. Oxidative Med. Cell. Longev. 2014, 2014, 360438. [CrossRef] [PubMed]

49. Chen, Z.; Fang, X.; Yuan, X.; Zhang, Y.; Li, H.; Zhou, Y.; Cui, X. Overexpression of Transcription Factor GmTGA15 Enhances Drought Tolerance in Transgenic Soybean Hairy Roots and Arabidopsis Plants. Agronomy 2021, 11, 170. [CrossRef]

50. Abid, M.; Tian, Z.; Ata-Ul-Karim, S.T.; Liu, Y.; Cui, Y.; Zahoor, R.; Jiang, D.; Dai, T. Improved tolerance to post-anthesis drought stress by pre-drought priming at vegetative stages in drought-tolerant and -sensitive wheat cultivars. Plant Physiol. Biochem. 2016, 106, 218-227. [CrossRef] [PubMed]

51. Wang, S.; Liang, D.; Li, C.; Hao, Y.; Ma, F.; Shu, H. Influence of drought stress on the cellular ultrastructure and antioxidant system in leaves of drought-tolerant and drought-sensitive apple rootstocks. Plant Physiol. Biochem. 2012, 51, 81-89. [CrossRef] [PubMed]

52. Abdelaal, K.A.A.; Rashed, S.H.; Hossain, A.; El Sabagh, A. Yield and quality of two sugar beet (Beta vulgaris L. ssp. vulgaris var. altissima Döll) cultivars are influenced by foliar application of salicylic acid, irrigation timing, and planting density. Acta Agric. Slov. 2020, 115, 273. [CrossRef]

53. Aghajanlou, F.; Mirdavoudi, H.; Shojaee, M.; Mac Sweeney, E.; Mastinu, A.; Moradi, P. Rangeland Management and Ecological Adaptation Analysis Model for Astragalus curvirostris Boiss. Horticulturae 2021, 7, 67. [CrossRef] 
54. Moradi, P.; Aghajanloo, F.; Moosavi, A.; Monfared, H.H.; Khalafi, J.; Taghiloo, M.; Khoshzaman, T.; Shojaee, M.; Mastinu, A. Anthropic Effects on the Biodiversity of the Habitats of Ferula gummosa. Sustainability 2021, 13, 7874. [CrossRef]

55. Zangani, E.; Afsahi, K.; Shekari, F.; Mac Sweeney, E.; Mastinu, A. Nitrogen and Phosphorus Addition to Soil Improves Seed Yield, Foliar Stomatal Conductance, and the Photosynthetic Response of Rapeseed (Brassica napus L.). Agriculture 2021, 11, 483. [CrossRef]

56. Sharma, P.; Dubey, R.S. Drought Induces Oxidative Stress and Enhances the Activities of Antioxidant Enzymes in Growing Rice Seedlings. Plant Growth Regul. 2005, 46, 209-221. [CrossRef]

57. Qayyum, A.; Razzaq, A.; Bibi, Y.; Khan, S.U.; Abbasi, K.S.; Sher, A.; Mehmood, A.; Ahmed, W.; Mahmood, I.; Manaf, A.; et al. Water stress effects on biochemical traits and antioxidant activities of wheat (Triticum aestivum L.) under In vitro conditions. Acta Agric. Scand. Sect. B Soil Plant Sci. 2017, 68, 283-290. [CrossRef]

58. Läuchli, A.; Grattan, S. Plant Growth and Development Under Salinity Stress. In Advances in Molecular Breeding Toward Drought and Salt Tolerant Crops; Metzler, J.B., Ed.; Springer: Dordrecht, The Netherlands, 2007; pp. 1-32. [CrossRef]

59. Roshdy, A.E.-D.; Alebidi, A.; Almutairi, K.; Al-Obeed, R.; Elsabagh, A. The Effect of Salicylic Acid on the Performances of Salt Stressed Strawberry Plants, Enzymes Activity, and Salt Tolerance Index. Agronomy 2021, 11, 775. [CrossRef]

60. Miura, K.; Tada, Y. Regulation of water, salinity, and cold stress responses by salicylic acid. Front. Plant Sci. 2014, 5, 4. [CrossRef] [PubMed]

61. Geilfus, C.-M. The pH of the Apoplast: Dynamic Factor with Functional Impact Under Stress. Mol. Plant 2017, 10, 1371-1386. [CrossRef] [PubMed]

62. Mccollum, T.G.; Huber, D.J.; Cantliffe, D.J. Soluble Sugar Accumulation and Activity of Related Enzymes during Muskmelon Fruit-Development. J. Am. Soc. Hortic. Sci. 1988, 113, 399-403.

63. Ribas-Carbo, M.; Taylor, N.L.; Giles, L.; Busquets, S.; Finnegan, P.M.; Day, D.A.; Lambers, H.; Medrano, H.l.; Berry, J.A.; Flexas, J. Effects of Water Stress on Respiration in Soybean Leaves. Plant Physiol. 2005, 139, 466-473. [CrossRef]

64. Mohammed, H.N.; Mahmud, T.M.M.; Edaroyati, M.W.P. Deficit Irrigation for Improving the Postharvest Quality of Lowland Tomato Fruits. Pertanika J. Trop. Agr. 2018, 41, 741-757.

65. Ghaderi, N.; Normohammadi, S.; Javadi, T. Morpho-physiological Responses of Strawberry (Fragariaxananassa) to Exogenous Salicylic Acid Application under Drought Stress. J. Agr. Sci. Technol. 2015, 17, 167-178.

66. Demiralay, M.; Saglam, A.; Kadioglu, A. Salicylic acid delays leaf rolling by inducing antioxidant enzymes and modulating osmoprotectant content in Ctenanthe setosa under osmotic stress. Turk. J. Biol. 2013, 37, 49-59. [CrossRef]

67. Sariñana-Aldaco, O.; Sánchez-Chávez, E.; Troyo-Diéguez, E.; Tapia-Vargas, L.M.; Díaz-Pérez, J.C.; Preciado-Rangel, P. Foliar Aspersion of Salicylic Acid Improves Nutraceutical Quality and Fruit Yield in Tomato. Agriculture 2020, 10, 482. [CrossRef]

68. Jahangirlou, M.R.; Akbari, G.A.; Alahdadi, I.; Soufizadeh, S.; Parsons, D. Grain Quality of Maize Cultivars as a Function of Planting Dates, Irrigation and Nitrogen Stress: A Case Study from Semiarid Conditions of Iran. Agriculture 2020, 11, 11. [CrossRef]

69. Sehgal, A.; Sita, K.; Siddique, K.H.M.; Kumar, R.; Bhogireddy, S.; Varshney, R.K.; HanumanthaRao, B.; Nair, R.M.; Prasad, P.V.V.; Nayyar, H. Drought or/and Heat-Stress Effects on Seed Filling in Food Crops: Impacts on Functional Biochemistry, Seed Yields, and Nutritional Quality. Front. Plant Sci. 2018, 9, 1705. [CrossRef] [PubMed]

70. Thakur, M.; Kumar, R. Foliar application of plant growth regulators modulates the productivity and chemical profile of damask rose (Rosa damascena Mill.) under mid hill conditions of the western Himalaya. Ind. Crop. Prod. 2020, 158, 113024. [CrossRef]

71. Gao, J.; Hao, X.; Thelen, K.D.; Robertson, G.P. Agronomic Management System and Precipitation Effects on Soybean Oil and Fatty Acid Profiles. Crop Sci. 2009, 49, 1049-1057. [CrossRef]

72. Carrera, C.; Martínez, M.J.; Dardanelli, J.; Balzarini, M. Water Deficit Effect on the Relationship between Temperature during the Seed Fill Period and Soybean Seed Oil and Protein Concentrations. Crop Sci. 2009, 49, 990-998. [CrossRef]

73. Ashrafi, E.; Razmjoo, K. Effect of Irrigation Regimes on Oil Content and Composition of Safflower (Carthamus tinctorius L.) Cultivars. J. Am. Oil Chem. Soc. 2010, 87, 499-506. [CrossRef]

74. Zunun-Pérez, A.Y.; Guevara-Figueroa, T.; Jimenez-Garcia, S.N.; Feregrino-Pérez, A.A.; Gautier, F.; Guevara-González, R.G. Effect of foliar application of salicylic acid, hydrogen peroxide and a xyloglucan oligosaccharide on capsiate content and gene expression associated with capsinoids synthesis in Capsicum annuum L. J. Biosci. 2017, 42, 245-250. [CrossRef]

75. Ghasemi, M.; Modarresi, M.; Babaeian Jelodar, N.; Bagheri, N.; Jamali, A. The Evaluation of Exogenous Application of Salicylic Acid on Physiological Characteristics, Proline and Essential Oil Content of Chamomile (Matricaria chamomilla L.) under Normal and Heat Stress Conditions. Agriculture 2016, 6, 31. [CrossRef]

76. Yousefzadi, M.; Sharifi, M.; Behmanesh, M.; Ghasempour, A.; Moyano, E.; Palazon, J. Salicylic acid improves podophyllotoxin production in cell cultures of Linum album by increasing the expression of genes related with its biosynthesis. Biotechnol. Lett. 2010, 32, 1739-1743. [CrossRef] [PubMed] 